OPEN ACCESS

Edited by:

Liping Liu,

Shanghai Ocean University, China

Reviewed by:

Yinghui Dong,

Zhejiang Wanli University, China

Zhiguo Dong,

Jiangsu Ocean University, China

Zhaoqun Liu,

Dalian Ocean University, China

*Correspondence:

Weiwei You

wwyou@xmu.edu.cn

Specialty section:

This article was submitted to

Marine Fisheries, Aquaculture and Living Resources,

a section of the journal

Frontiers in Marine Science

Received: 23 August 2021

Accepted: 19 October 2021

Published: 08 November 2021

Citation:

Zhang M, Gao X, Lyu M, Lin S, Su Y, Luo X, You W and Ke C (2021) Effects of Flow Velocity on the Growth and Survival of Haliotis discus hannai

Larvae in the Recirculating Upflow

System From the Point of Energy

Metabolism

Front. Mar. Sci. 8:763269

doi: 10.3389/fmars.2021.763269

\section{Effects of Flow Velocity on the Growth and Survival of Haliotis discus hannai Larvae in the Recirculating Upflow System From the Point of Energy Metabolism}

\author{
Mo Zhang 1,2,3, Xiaolong Gao ${ }^{1,2,3}$, Mingxin Lyu ${ }^{1,2,3}$, Shihui Lin ${ }^{1,2,3}$, Ying Su', Xuan Luo ${ }^{1,2,3}$, \\ Weiwei You ${ }^{1,2,3 *}$ and Caihuan $\mathrm{Ke}^{1,2,3}$ \\ 1 State Key Laboratory of Marine Environmental Science, Xiamen University, Xiamen, China, ${ }^{2}$ College of Ocean and Earth \\ Sciences, Xiamen University, Xiamen, China, ${ }^{3}$ Fujian Key Laboratory of Genetics and Breeding of Marine Organisms, Xiamen \\ University, Xiamen, China
}

For the abalone Haliotis discus hannai, attachment and metamorphosis are crucial stages in the transition from planktonic to benthic life. Increasing the larval metamorphosis rate by artificially controlling the external environment and simulating natural seawater flow is vital to enhance the hatchery efficiency of $H$. discus hannai. Thus, in the current study, an upflow recirculating aquaculture unit was designed for the rearing of larval abalone, and the larval hatching rate, survival rate, mode of energy metabolism, and expression levels of metamorphosis-related genes at different flow velocities $(0,5,10,20$, and $40 \mathrm{~L} / \mathrm{h})$ were compared and analyzed. At flow velocities less than $20 \mathrm{~L} / \mathrm{h}$, no significant differences occurred in larval hatching, survival, and metamorphosis rates, whereas significant differences were recorded at flow rates of 20 and $40 \mathrm{~L} / \mathrm{h}$. Differences were also observed in the activity of enzymes, such as hexokinase $(H K)$, pyruvate kinase $(P K)$, lactate dehydrogenase $(\mathrm{LDH})$, succinate dehydrogenase $(\mathrm{SDH})$, and malate dehydrogenase $(\mathrm{MDH})$, as well as glycogen levels, at the higher flow rates. These results suggested that velocity in excess of a certain limit leads to a higher glycolysis rate and transition of energy utilization from aerobic to anaerobic metabolism for the abalone larvae. Compared with conventional still-water aquacultural systems, the flow velocity at 5-10 L/h could maintain the water environment stability, and avoid both fertilized eggs from being densely deposited before hatching and the consumption of energy needed to resist high flow velocities. Thus, these results are useful references to enhance the hatchery efficiency, and to conduct large-scale rearing, of abalone larvae.

Keywords: Haliotis discus hannai, flow velocity, larval rearing, energy metabolism, gene expression 


\section{INTRODUCTION}

Haliotis discus hannai is one of the most important mariculture shellfish species in China. In 2019, abalone aquaculture production reached 180,300 tons, accounting for $90 \%$ of the total production worldwide (China Bureau of Fisheries, 2021). However, there are still many concerns and problems associated with abalone farming and artificial reproduction. For example, the low larval metamorphosis rate constrains the efficient and large-scale development of the abalone-rearing industry. Generally, the sperm and eggs are collected and placed directly in a small container $(5 \mathrm{~L}$ ) for artificial fertilization. Fertilized eggs are then directly transferred to the rearing pond for subsequent rearing. However, this rearing method is likely to lead to highdensity accumulation and adhesion of fertilized eggs in a specific part of the pond, while dead eggs and decomposition products pollute the water and affect the larval survival rate. Thus, the postlarval metamorphosis rate is often less than $5 \%$ under this rearing mode in southern China, which is less than the flowthrough rearing system used in northern China (Wu and Zhang, 2016). Therefore, it is necessary to develop a new system to improve the survival and metamorphosis rate of larvae.

Energy storage and release are essential activities in all organisms, and enzymes catalyze the metabolic reactions involved in these processes (Natalia et al., 2004). Such enzymes can, to a certain extent, regulate energy production in invertebrates. The activity of key energy metabolism enzymes in this pathway is crucial to the amount of energy generated (Friedrich, 1998). Respiratory metabolism is a crucial part of bioenergy metabolism, which can reflect the metabolic characteristics, physiological conditions, and nutritional status of the animal and its adaptability to its external environment. It is also considered an important field in aquatic bioenergetics and nutritional physiology research (Bao et al., 2018). Under anoxic conditions, aerobic metabolism of the fish Astronotus crassipinnis is inhibited and the activity of lactate dehydrogenase (LDH) continuously increases with the extension of anoxia (Heinrichs-Caldas et al., 2019). Similarly, when the shrimp Litopenaeus vannamei was exposed to hypoxic $(1.57 \pm 0.2 \mathrm{mg} / \mathrm{L})$ conditions, the expression levels of LDH in glycolysis and phosphoenolpyruvate carboxylase in the gluconeogenic pathway increased (Reyes-Ramos et al., 2018); whereas, after $4 \mathrm{~h}$ of chasing prey, the activity of pyruvate kinase in the liver of rainbow trout was decreased (López-Patiño et al., 2014). Ivanina et al. (2011) found that the eastern oyster Crassostrea virginica had a higher free glycogen content and significantly enhanced hexokinase activity under hypoxic stress compared with control animals. Gao et al. (2017) considered that a decrease in salinity would lead to the enhanced activity of energy-metabolizing enzymes (i.e., hexokinase and pyruvate kinase) in the liver of the abalone $H$. discus hannai, suggesting that an increase in glycolysis rate would increase the energy needs of the body in a response to drastic changes in salinity. For marine invertebrates, energy reserves in the embryonic and larval stages are generally not enough to fulfill the total energy metabolism needs during metamorphism (Shilling and Manahan, 1990).
Especially for lecithotrophic larval abalone, which depend on egg yolk nutrients, a longer planktonic period will exhaust the nutrients in the egg yolk, reducing the survival and growth rates of the juveniles (Maldonado and Young, 1999; Marshall et al., 2003; Thiyagarajan et al., 2007). The metabolic rate of Balanus balanoides increased during metamorphosis, but the protein and lipids as energy storage substances significantly reduced (Lucas et al., 1979). When metamorphosing, bivalve mollusks can directly absorb amino acids dissolved in seawater (Manahan and Crisp, 1983). The energy needs of Haliotis rufescens during larval metamorphosis are met by nutrients from its surroundings (e.g., dissolved organic material), but the oxygen consumption rate and glucose and alanine contents of larvae significantly increase during this process (Shilling et al., 1996). Thus, detection of the variation in energy metabolism enzyme activity can indicate the ability of the body to adapt to environmental change.

Larval metamorphosis of most marine invertebrate, which is an irreversible process and accompanied by high mortality, is triggered by external factors (Williamson et al., 2000). If environmental factors (e.g., temperature or salinity) change, the regulatory mechanism of the invertebrate neuroendocrine system would secrete hormones triggered by the stress response, leading to a series of physiological and biochemical reactions, including metabolism of principal energy substances, immunity, and respiration (Dong et al., 2017). In the short-wavelength blue/green light and dark environments, larval hatching rate and survival rate of $H$. discus hannai were significantly higher than in the long-wavelength red/orange group, suggesting that more energy accumulated during metamorphosis in blue/green light and dark environments (Gao et al., 2017). Wang et al. (2016) found that the expression levels of IGFBP7 began to rise rapidly during the early trochophore stage and peaked during the metamorphosis stage. Given that IGFBP7 was subject to RNA interference (RNAi), the larval metamorphosis rate in the group subject to RNAi was significantly reduced by $31.81 \%$ compared with the untreated group, suggesting that IGFBP7 has a role in larval metamorphosis in $H$. diversicolor. The addition of adrenaline (AD) and noradrenaline (NA) within a concentration range of $10-100 \mu \mathrm{M}$ significantly increased the larval metamorphosis rate of Meretrix meretrix; thus, the change in hormone and gene expression level could be used as an indicator to anticipate the initiation of metamorphosis (Wang et al., 2006).

In the current study, a new abalone larval upflow recirculating aquaculture system was constructed. The running seawater flow conditions for larval development were simulated by different velocities, during which water quality, energy metabolic enzyme activity, the concentration of energy-related substances (i.e., protein, glycogen, and triglyceride) and the expression levels of metamorphosis-related genes were evaluated to screen out appropriate velocities facilitating the hatching, survival and attachment metamorphosis of abalone larvae. The study provides a reference for enriching our basic biological understanding of abalone larval development and for improving the rearing efficiency of the abalone industry. 


\section{MATERIALS AND METHODS}

\section{Source and Acclimation of Experimental Abalones}

The experiment was carried out at Fuda Abalone Farming Company (Jinjiang, Fujian). For adult abalones used in the experiment, the shell length was $75.15 \pm 6.17 \mathrm{~mm}$, shell width was $50.33 \pm 5.85 \mathrm{~mm}$, and body weight was $63.22 \pm 5.01 \mathrm{~g}$. Female and male abalones selected for the study had intact shells and feet, with gonadal development at Stage III (Ebert and Houk, 1984). During their acclimation, the water temperature was $19^{\circ} \mathrm{C}$, salinity was $31 \pm 1, \mathrm{pH}$ was 7.9 , and dissolved oxygen concentration was $>6 \mathrm{mg} / \mathrm{L}$, under a natural light/dark cycle. The abalones were fed with Gracilaria lemaneiformis daily at 17:00 h, at an amount that was $3 \%$ of the wet weight of the abalones.

\section{Induced Egg-Laying}

The female:male ratio of the abalones for induced egg-laying was 10:4. In the evening, the brood stocks were selected, dried in the shade for $1 \mathrm{~h}$, and then male and female abalones were separately put in ultraviolet (UV)-radiated seawater $(220 \mathrm{~V}$, $40 \mathrm{~W}, 500 \mathrm{mWh}^{-1}$ ). Once the parent abalones laid sperm and eggs, artificial insemination was then performed. To shield the developing embryos from any adverse effect from the overly high concentration of sperm, eggs were washed repeatedly to remove excessive sperm, resulting in eight to ten sperm around one egg, as viewed under a field microscope.

\section{Experimental Unit}

Four sets of conical recirculating aquaculture systems were used as the experimental unit (Figure 1). Each unit comprised the aquaculture system and the water treatment system. Water flowed in at the bottom of each system, which comprised five transparent conical aquaculture containers $(7.5 \mathrm{~L})$, flowmeters, inlet pipes, venturis, one-way valves, valves, filter drums, and drain pipes; the water treatment system comprised a filter tank, filter partition, water pump, UV disinfection lamp, aeration disk, thermostat, and air pump. At the bottom of the filter partition, a layer of ceramic rings and pelelith formed the first layer of filtering material, on which a layer of biochemical cottons with different pore diameters were laid. The aeration disk and thermostat were placed at the bottom of the filter tank. The water for rearing was first passed through the filters, exposed to a UV disinfection lamp, and then returned to each conical container from the base. Before the pump was turned on, all water valves and drain valves on the bottom of the containers were closed and then opened once the pump started running. The flow velocity was controlled by a flowmeter, 1 water outlet $(\varphi 2 \mathrm{~cm}, 10 \mathrm{~cm}$ from the tip of the cylinder) was placed on the cylindrical side wall of each conical container, a circular filter drum $(\varphi 13 \mathrm{~cm}$, thickness: $3 \mathrm{~cm}$, with a 100 -mesh screen adhered to each side) was joined to the outlet pipe so that larvae would not flow out with the water. An outfall was further placed at the bottom of the container. After the experiment, the valves were opened and the larvae that were about to enter the metamorphosis stage were collected with screens.

\section{Experimental Design}

Four velocity treatment groups $(5,10,20$, and $40 \mathrm{~L} / \mathrm{h})$ were designed for the experiment, whereas a still-water group $(0 \mathrm{~L} / \mathrm{h})$ in the same recirculating water aquaculture system was used as the control. Once the experiment started, fertilized eggs were taken and transferred to the different velocity groups at a set density of $10 \mathrm{ind} / \mathrm{ml}$; each group had four replicates. In the still-water group, no aeration was provided until larvae developed to the trochophore stage, at which point slight aeration was provided. Before the fertilized eggs developed into trochophores, the larval hatching rate, abnormality rate, and density were recorded in each group. Any larvae found with incomplete cilia, egg-shell damage, mulberry cells bulging into irregular shapes, or developmental retardation were considered to be deformed (Zhou et al., 2011). The development of embryos and larvae was observed under a microscope (Olympus CX22, Japan). When the larvae had developed into the secondary shell stage, their sizes were measured using a stage micrometer. Before each random sampling, the water was stirred lightly with a glass rod so that the larvae were evenly distributed. Then, 30 larvae were sampled from each group for measurement. If the fourth tubule on cephalic tentacles was observed, this indicated that the larva was about to enter the metamorphose stage. Water samples were randomly taken four times in each container, and the density of larvae in each group was counted for calculation of the survival rate; all larvae in each group were then collected using a filtering screen.

Throughout the experiment, the water temperature, salinity, $\mathrm{pH}$, and dissolved oxygen concentration in each group was measured by using a YSI-556MPS portable multiparameter water quality measuring instrument (Yellow Springs Instruments Inc., $\mathrm{OH}$, United States). After larvae were collected, the water was sampled to determine the TAN, $\mathrm{NO}_{2}-\mathrm{N}$, and $\mathrm{NO}_{3}-$ $\mathrm{N}$ concentrations. Each group was sampled three times and the concentrations were determined by SEAL Analytical-AA3 (Germany SEAL Analytical GmbH, Norderstedt, Germany). In the $0 \mathrm{~L} / \mathrm{h}$ group, trochophores were collected with screens once they floated. The screens were used to remove all dead eggs and exchange water, with fresh water replenished into the rearing container. Before larval metamorphosis, aeration was provided continuously, but no water was exchanged.

Subsequently, the larvae collected from each group were transferred to glass containers of the same size $(\varphi 15 \mathrm{~cm}$, height: $8 \mathrm{~cm}$ ) at a set density of $1 \mathrm{ind} / \mathrm{ml}$, and polythene membranes $(80 \mathrm{~mm} \times 80 \mathrm{~mm})$ with benthic diatoms were fixed to the bottom of each container. In the absence of planktonic larvae from the water, a section of polythene membranes $(20 \mathrm{~mm} \times 20 \mathrm{~mm})$ was randomly cut, and the settlement and metamorphosis rate of larvae were determined. Before larval metamorphosis, a low level of aeration was applied, to the extent that the dissolved oxygen concentration was not less than $6 \mathrm{mg} / \mathrm{L}$. The cut section was then fixed in a $4 \%$ formaldehyde solution and placed under a $4 \times 10$ magnification microscope; 30 larvae were measured with reference to a stage micrometer, and the metamorphosis rate, size of settlement and metamorphosis, and the time required for completion of metamorphosis were determined. Successful 


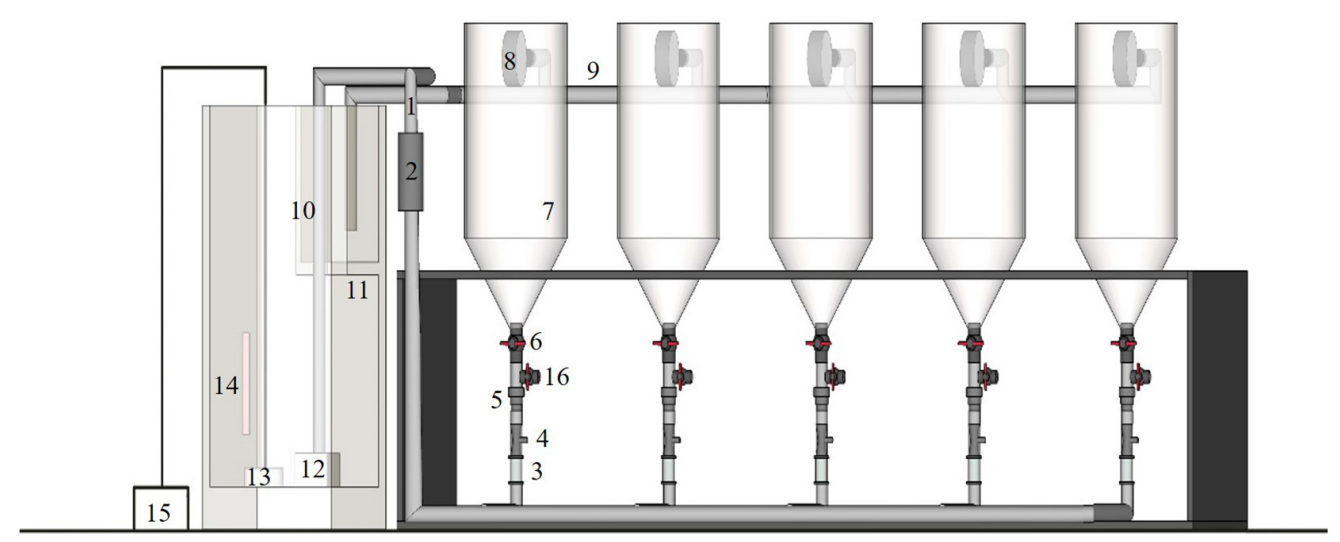

FIGURE 1 | Experimental RAS configuration: (1) inlet pipe; (2) ultraviolet disinfection lamp; (3) flow meter; (4) venturis; (5) one-way valves; (6) valves; (7) transparent cone container; (8) filter drums; (9) drain pipe; (10) filter tank; (11) filter partition; (12) water pump; (13) aeration disk; (14) thermostat; (15) air pump; (16) outfall.

metamorphosis of larvae was identified with reference to Vicose et al. (2007). The remaining larvae collected were transferred to a centrifuge tube, immediately stored in liquid nitrogen, until being used to assess larval biochemical composition, metabolic enzyme activity, and metamorphosis-related gene expression levels. The water used during the experiment was also subject to precipitation and sand filtration and had the same salinity and $\mathrm{pH}$ as during the acclimation period; the TAN concentration was no higher than $0.1 \mathrm{mg} / \mathrm{L}$. During the experiment, the surrounding air temperature was maintained at $20^{\circ} \mathrm{C}$ using an air conditioner.

\section{Assessing the Biochemical Composition of Larvae}

The biochemical components of larvae were determined using a test kit supplied by the Jiancheng Institute of Bioengineering. Briefly, $0.1 \mathrm{~g}$ of larvae were placed in a test tube, to which $1 \mathrm{~mL}$ $0.86 \%$ normal saline was added; the tube was then transferred to an ice bath for grinding. After dipping with Coomassie Brilliant Blue, the solution turned blue, and the protein concentration of the specimen was calculated by detecting the absorbance at $595 \mathrm{~nm}$. The method proposed by Gao et al. (2016) was used to determine the lactic acid content of the larvae. Briefly, with $\mathrm{NAD}^{+}$as the hydrogen acceptor, $\mathrm{LDH}$ catalyzes the dehydrogenation of lactate to produce pyruvate, turning $\mathrm{NAD}^{+}$ into NADH. PMS transferred hydrogen to reduce NBT to a purple color, and the absorbance of the color material was linearly related to the lactic acid content at $530 \mathrm{~nm}$; the lactic acid content was calculated by detecting the absorbance with ELISA.

To determine the triglyceride (TG) content, a homogenate was prepared with isotonic buffer solution at a ratio of 1:9 (weight: volume) using the GPO-PAP method and centrifuged at $2500 \times g$ for $10 \mathrm{~min}$. Then, $10 \%$ homogenate was taken as the supernatant and the TG content was calculated by detecting the absorbance at $510 \mathrm{~nm}$ with ELISA.

Creatine kinase catalyzes ATP and creatine to generate creatine phosphate. The ATP content was determined using phosphomolybdic acid colorimetry, and calculated by detecting the absorbance at $636 \mathrm{~nm}$ with ELISA.
Glycogen can be dehydrated under the action of concentrated sulfuric acid to produce aldehyde derivatives, and then reacted with anthrone to form a blue compound; thus, colorimetry was performed with the standard glucose solution treated in the same manner as described earlier. The larvae were taken at a specimen weight (mg): hydrolyzate volume $(\mu \mathrm{L})$ of $1: 3$, added to a test tube, then boiled in a water bath for $20 \mathrm{~min}$. The sample was then cooled, a Color-substrate solution was added and the test tube then was further boiled for $5 \mathrm{~min}$. After cooling, the glycogen content was calculated by detecting the absorbance at $620 \mathrm{~nm}$.

\section{Assay of Larval Metabolic Enzyme Activity}

The HK, PK, SDH, MDH, and LDH content was also determined using a test kit supplied by Jiancheng Institute of Bioengineering. To do so, $0.1 \mathrm{~g}$ larvae were placed in test tube and $1 \mathrm{~mL}$ homogenous medium ( $\mathrm{pH} 7.4,0.01 \mathrm{~mol} / \mathrm{L}$ Tris- $\mathrm{HCl}, 1 \mathrm{mmol} / \mathrm{L}$ EDTA-2Na, $0.01 \mathrm{~mol} / \mathrm{L}$ sucrose, $0.8 \%$ sodium chloride solution) was added; the tube was then centrifuged at $10,000 \times g$ for $30 \mathrm{~s}$.

HK catalyzes glucose to synthesize glucose-6-phosphate, the dehydrogenation of which is further catalyzed by glucose 6phosphate dehydrogenase to NADPH. The activity of HK was calculated by detecting the special absorption peak of NADPH at $340 \mathrm{~nm}$ using a UV spectrophotometer. At $37^{\circ} \mathrm{C}$ and $\mathrm{pH}$ 7.6, an enzyme activity unit was defined as $1 \mu \mathrm{mol}$ PEP converted by $1 \mathrm{~g}$ tissue protein into pyruvate per minute; the activity of PK was then calculated by detecting the absorbance at $340 \mathrm{~nm}$ using a UV spectrophotometer. The activity of SDH was defined as 1 specific activity unit that reduced the absorbance of the reaction system by 0.01 per $\mathrm{mg}$ protein per minute. The activity of SDH was calculated by detecting the reducing rate of 2,6DPIP at $600 \mathrm{~nm}$ using a visible light spectrophotometer. The $\mathrm{MDH}$-catalyzed redox reaction was accompanied by reduced absorbance at $340 \mathrm{~nm}$. The activity of $\mathrm{MDH}$ was calculated by detecting the change in absorbance per minute using a UV spectrophotometer. After $\mathrm{LDH}$ catalyzes the conversion of lactic acid to pyruvate, pyruvate reacts with 2,4-dinitrophenylhydrazin to produce pyruvate dinitrophenylhydrazone (which appears 
brownish red in alkaline solution); the activity of $\mathrm{LDH}$ can then be calculated by detecting the absorbance at $440 \mathrm{~nm}$ (Gao et al., 2016).

\section{Gene Expression Analysis}

The larvae that settled and metamorphosed were collected using a screen and then ground in a mortar with liquid nitrogen. RNA was extracted with TRIzol (Invitrogen, United States) and reverse transcription was performed by using the PrimeScript ${ }^{\mathrm{TM}} \mathrm{RT}$ Reagent Kit with gDNA Eraser (Takara, Japan). Three replicates samples were mixed and diluted five times, and then used as the template for real-time fluorescent quantitative PCR using the following reaction system: $5 \times$ gDNA Eraser Buffer $5 \mu \mathrm{L}$; gDNA Eraser $1 \mu \mathrm{L}$; total RNA $500 \mathrm{ng}$; RNase Free $\mathrm{dH}_{2} \mathrm{O}$ added up to $10 \mu \mathrm{L}$; at $42^{\circ} \mathrm{C}$ for $2 \mathrm{~min}$; PrimeScriptRT Enzyme Mix I $1 \mu \mathrm{L}$, RT Primer Mix $4 \mu \mathrm{L}, 5 \times$ PrimeScript Buffer $4 \mu \mathrm{L}$, RNase Free $\mathrm{dH}_{2} \mathrm{O} 1 \mu \mathrm{L}$ were then added to the above reaction liquid at $37^{\circ} \mathrm{C}$ for $15 \mathrm{~min}, 85^{\circ} \mathrm{C}$ at $5 \mathrm{~s}$, and then kept at $4^{\circ} \mathrm{C}$ and diluted five times before use.

The primers for fluorescence quantification were designed according to the ORF region of insulin-like growth factor binding protein 7 (IGFBP7) and $\alpha 2$ - Adrenoceptor (a2ADR); the sequence of each primer is given in Table 1 . The reaction system had a volume of $20 \mu \mathrm{L}$, comprising $2 \times$ TB Green TM Premix Ex Taq TM (Takara, Japan) $10 \mu \mathrm{L}$; forward primer $(10 \mu \mathrm{M})$ $0.6 \mu \mathrm{L}$, reverse primer $(10 \mu \mathrm{M}) 0.6 \mu \mathrm{L}, \mathrm{cDNA}$ template $1.6 \mu \mathrm{L}$, and $\mathrm{dH}_{2} \mathrm{O} 7.2 \mu \mathrm{L}$. The samples were mixed in a PCR tube for amplification, under the following reaction conditions: initial denaturation at $94^{\circ} \mathrm{C}$ for $30 \mathrm{~s}$; under the cycling conditions: $94^{\circ} \mathrm{C}$ for $5 \mathrm{~s}, 60^{\circ} \mathrm{C}$ for $30 \mathrm{~s}$, with 40 cycles in total; the dissolution curve was analyzed at the end of the experiment. For individual RNA samples and genes, all PCR analyses were set with three replicates. The target gene mRNA level was calibrated by using the realtime PCR Ct $\left(2^{-\Delta \Delta} \mathrm{Ct}\right)$ relative quantitative method, with the reference gene $\beta$-actin treated as the quantitative standard.

\section{Outcome Calculations}

Outcomes were calculated as follows:

Hatching rate $=$ (number of trochophore larvae within the field of view/total number of fertilized eggs within the field of view) $\times 100 \%$.

Abnormality rate $=$ (number of deformed embryos within the field of view/total number of fertilized eggs within the field of view) $\times 100 \%$.

TABLE 1 | Oligonucleotide primers used in qRT-PCR.

\begin{tabular}{|c|c|c|c|c|}
\hline Gene & Sequence $\left(5^{\prime}-3^{\prime}\right)$ & $\begin{array}{c}\text { Efficiency } \\
(\%)\end{array}$ & $\begin{array}{l}\text { Size } \\
\text { (bp) }\end{array}$ & References \\
\hline \multirow[t]{2}{*}{ IGFBP7 } & F: CCCTTGCACCAGGCTTAGCCT & 99.26 & 173 & MT345605.1 \\
\hline & R: GAACTCCTCCCAATTCCCG & & & \\
\hline \multirow[t]{2}{*}{$\alpha 2 A D R$} & F: CCGCTITCTTAGTCCCGCA & 101.75 & 193 & MZ359214 \\
\hline & R: GAACCGGTAACCGTCTTCCGTTA & & & \\
\hline \multirow[t]{2}{*}{$\beta$-Actin } & F: CCACTTGGTCCATTTCG & 100.46 & 162 & MW387000 \\
\hline & R: GGACTGGATITCCGGCCA & & & \\
\hline
\end{tabular}

IGFBP7, insulin-like growth factor binding protein 7; a2ADR, a2-Adrenoceptor; F, Forward primer; $R$, Reverse primer.
Survival rate $=$ (total number of trochophores/number of larvae about to enter the metamorphosis stage).

Settlement and metamorphosis rate $=$ (number of juvenile abalones on polythene membranes/number of planktonic larvae) $\times 100 \%$.

\section{Statistical Analysis}

Data were expressed as the mean \pm standard deviation. Logarithmic transformation was performed on data relating to hatching rate, abnormality rate, metamorphosis rate, and survival rate, to the extent that the homogeneity test of variance and the standard normal distribution were satisfied. Comparative analysis of the effects of flow velocity on the larval hatching rate, survival, biochemical composition, and metamorphosis-related gene expression levels was performed using SPSS18.0 coupled with one-way ANOVA and Tukey multiple comparisons, with $P<0.05$ being significant.

\section{RESULTS}

\section{Water Quality Monitoring}

Under different flow velocities, there was no significant difference in the temperature, dissolved oxygen concentration, salinity, $\mathrm{pH}$, and $\mathrm{NO}_{3}-\mathrm{N}$ concentration of the water body (Table 2). In the control group, the TAN-N and $\mathrm{NO}_{2}-\mathrm{N}$ concentrations were significantly higher than in any other velocity group $(P<0.05)$. By contrast, there was no significant difference in the concentrations of TAN-N and $\mathrm{NO}_{2}-\mathrm{N}$ among the velocity groups $(P>0.05)$.

\section{Hatching and Abnormality Rates}

The larval hatching rate varied significantly under different velocities. No significant difference was identified in larval hatching rate between the 0,5 , and $10 \mathrm{~L} / \mathrm{h}$ groups, but each was significantly higher than that in the $40 \mathrm{~L} / \mathrm{h}$ group (Figure 2A, $P<0.05)$. The larval abnormality rate tended to increase as the flow velocity increased (Figure 2B). At $20 \mathrm{~L} / \mathrm{h}$, even though the larval abnormality rate was significantly higher than that in the 0 , 5, or $10 \mathrm{~L} / \mathrm{h}$ groups, it was significantly lower than that in the $40 \mathrm{~L} / \mathrm{h}$ group $(P<0.05)$.

\section{Survival Rate and Metamorphosis Rate}

Velocity had significant effects on the larval survival and metamorphosis rates. When the flow velocity increased to $40 \mathrm{~L} / \mathrm{h}$, the larval survival rate and metamorphosis rate were significantly lower than in the 0,5 and $10 \mathrm{~L} /$ h groups (Figures $2 \mathrm{C}, \mathbf{D}, P<0.05$ ). Even though no significant difference was identified in the larval survival rate and metamorphosis rate between the 0,5 and $10 \mathrm{~L} / \mathrm{h}$ groups, each was significantly higher than that in the $20 \mathrm{~L} / \mathrm{h}$ group $(P<0.05)$.

\section{Larval Size}

No significant difference was identified in larval sizes at the formation of the secondary shell stage among the $0,5,10$, and $20 \mathrm{~L} / \mathrm{h}$ groups, whereas larval sizes in $5,10 \mathrm{~L} / \mathrm{h}$ group 
TABLE 2 | Effects of flow velocity on water quality parameters based on one-way ANOVA.

\begin{tabular}{|c|c|c|c|c|c|c|c|}
\hline \multirow[t]{2}{*}{ Flow velocity (L/h) } & \multicolumn{7}{|c|}{ Water quality parameters } \\
\hline & Temperature $\left({ }^{\circ} \mathbf{C}\right)$ & Salinity & $\mathrm{pH}$ & DO (mg/L) & TAN-N (mg/L) & $\mathrm{NO}_{2}-\mathrm{N}(\mathrm{mg} / \mathrm{L})$ & $\mathrm{NO}_{3}-\mathrm{N}(\mathrm{mg} / \mathrm{L})$ \\
\hline 0 & $18.08 \pm 0.12$ & $31.28 \pm 1.98$ & $7.81 \pm 0.17$ & $6.51 \pm 0.38$ & $0.037 \pm 0.016^{a}$ & $0.005 \pm 0.001^{a}$ & $0.982 \pm 0.064$ \\
\hline 5 & $17.98 \pm 0.10$ & $30.71 \pm 2.03$ & $7.75 \pm 0.12$ & $6.58 \pm 0.49$ & $0.025 \pm 0.009^{b}$ & $0.003 \pm 0.001^{b}$ & $0.965 \pm 0.082$ \\
\hline 10 & $17.84 \pm 0.31$ & $30.09 \pm 1.64$ & $7.79 \pm 0.25$ & $6.54 \pm 0.57$ & $0.022 \pm 0.015^{b}$ & $0.002 \pm 0.002^{b}$ & $0.953 \pm 0.051$ \\
\hline 20 & $18.02 \pm 0.27$ & $31.25 \pm 1.47$ & $7.75 \pm 0.20$ & $6.61 \pm 0.44$ & $0.020 \pm 0.013^{b}$ & $0.002 \pm 0.001^{b}$ & $0.965 \pm 0.068$ \\
\hline 40 & $18.05 \pm 0.22$ & $31.16 \pm 2.15$ & $7.80 \pm 0.24$ & $6.68 \pm 0.27$ & $0.019 \pm 0.011^{b}$ & $0.002 \pm 0.001^{b}$ & $0.977 \pm 0.032$ \\
\hline
\end{tabular}

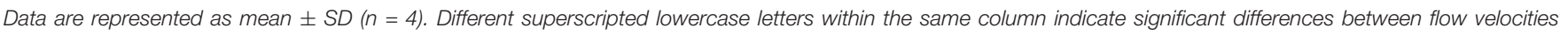
$(P<0.05)$.

$\mathrm{DO}$, dissolved oxygen; TAN-N, total nitrogen; $\mathrm{NO}_{2}-\mathrm{N}$, nitrite nitrogen; $\mathrm{NO}_{3}-\mathrm{N}$, nitrate nitrogen.
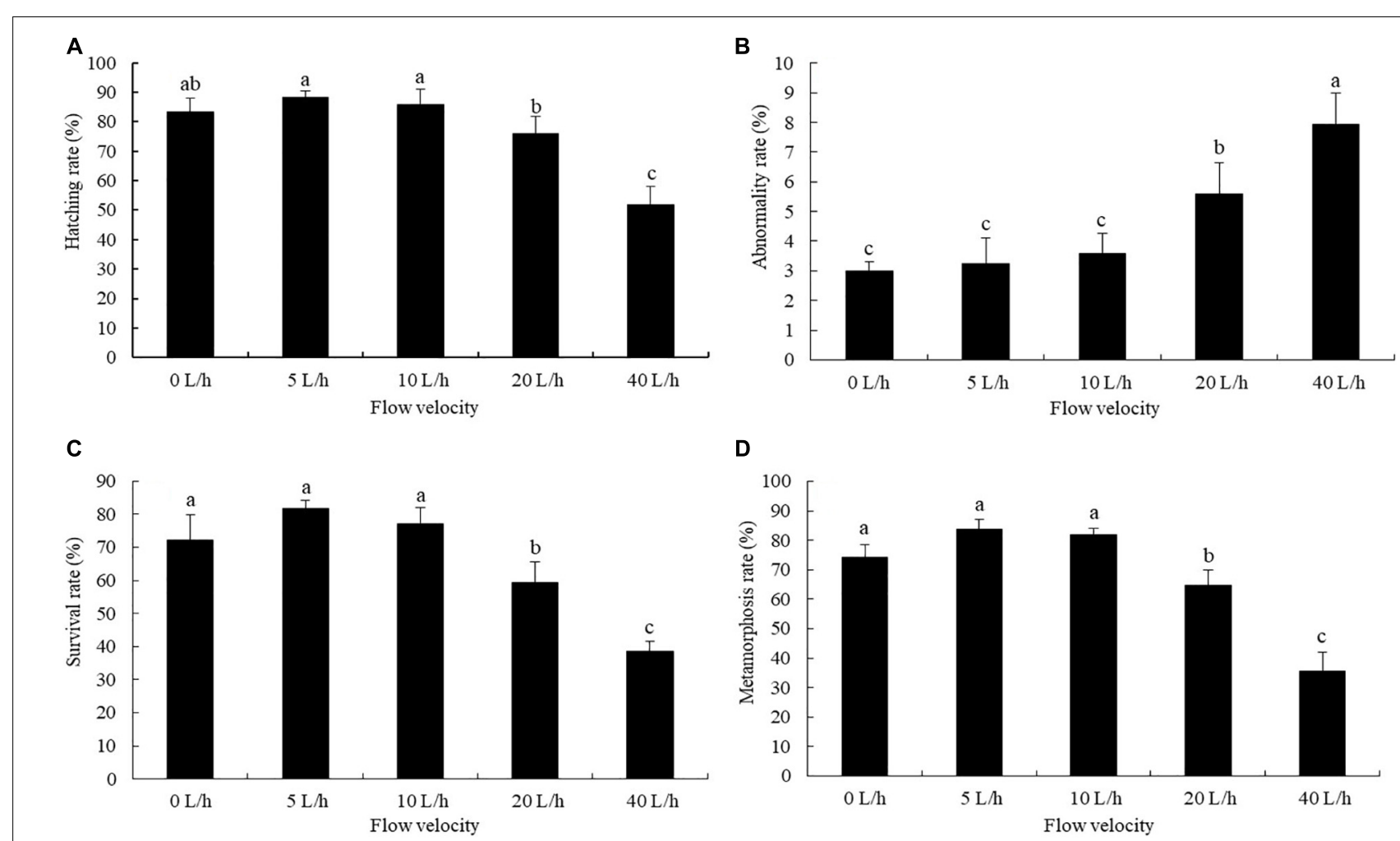

FIGURE 2 | Effects of flow velocity on the hatching rate (A), abnormality rate (B), survival rate (C), and metamorphosis rate (D) of Pacific abalone $H$. discus hannai larvae. Values are means and standard deviation of four replicates (means $\pm \mathrm{SD} ; n=4$ ). Significant variations were found by one-way analysis of variance, $P<0.05$, followed by Tukey test. Different letters denote significant differences between flow velocities.

were significantly smaller than in the $40 \mathrm{~L} / \mathrm{h}$ group (Table 3 , $P<0.05)$. The size at metamorphosis varied significantly at different velocities. Larval size in the 20 and $40 \mathrm{~L} / \mathrm{h}$ groups was significantly higher than in any other group $(P<0.05)$. The time required for the larval metamorphosis in the 5 and $10 \mathrm{~L} / \mathrm{h}$ groups was significantly shorter than in any other flow velocity group $(P<0.05)$. The time required for larval metamorphosis was longest in the $40 \mathrm{~L} / \mathrm{h}$ group, but was not significantly different from that in the $20 \mathrm{~L} / \mathrm{h}$ group $(P>0.05)$.

\section{Biochemical Composition}

No significant differences were identified in larval protein content among the velocity groups (Table $4, P>0.05$ ). The larval TG content in the 5 and $10 \mathrm{~L} / \mathrm{h}$ groups was significantly higher than in any other group $(P<0.05)$, being lowest in the $20 \mathrm{~L} / \mathrm{h}$ group. Velocity had significant effects on the larval lactic acid content. No significant difference was identified in larval lactic acid content among the 0,5 , and $10 \mathrm{~L} / \mathrm{h}$ groups, but each was significantly lower than in the $40 \mathrm{~L} / \mathrm{h}$ group $(P<0.05)$. The larval ATP content also increased with flow velocity, with the $5 \mathrm{~L} / \mathrm{h}$ group having the lowest ATP content, whereas the ATP content in the $40 \mathrm{~L} / \mathrm{h}$ group was significantly higher than in the 0,5 , and $10 \mathrm{~L} / \mathrm{h}$ groups $(P<0.05)$. No significant difference was identified in larval glycogen content in the $0,5,10$, or $20 \mathrm{~L} / \mathrm{h}$ groups, but was significantly reduced when the velocity increased to $40 \mathrm{~L} / \mathrm{h}$ $(P<0.05)$. 
TABLE 3 | Performance of $H$. discus hannai larvae from completion of larvae shell to metamorphosis according to flow velocities.

\begin{tabular}{|c|c|c|c|}
\hline Flow velocity (L/h) & $\begin{array}{l}\text { Completion of larvae shell (shell } \\
\text { length } \times \text { shell width, } \mu \mathrm{m} \text { ) }\end{array}$ & $\begin{array}{l}\text { Metamorphosis size (shell } \\
\text { length } \times \text { shell width, } \mu \mathrm{m} \text { ) }\end{array}$ & $\begin{array}{c}\text { Metamorphosis time } \\
\text { (h) }\end{array}$ \\
\hline 0 & $261.11 \pm 4.34 \times 206.65 \pm 5.98^{a b}$ & $381.49 \pm 4.86 \times 269.57 \pm 6.43^{b}$ & $28.57 \pm 0.73^{b}$ \\
\hline 5 & $255.33 \pm 4.92 \times 203.75 \pm 6.67^{b}$ & $372.51 \pm 6.61 \times 260.54 \pm 7.79^{b}$ & $10.92 \pm 0.41^{\mathrm{c}}$ \\
\hline 10 & $251.69 \pm 6.05 \times 201.67 \pm 5.01^{b}$ & $375.30 \pm 8.97 \times 262.13 \pm 4.39^{b}$ & $22.46 \pm 0.33^{c}$ \\
\hline 20 & $266.75 \pm 7.36 \times 208.77 \pm 7.59^{a b}$ & $405.41 \pm 5.55 \times 287.17 \pm 8.39^{a}$ & $33.79 \pm 0.29^{a}$ \\
\hline 40 & $272.58 \pm 4.98 \times 214.02 \pm 6.15^{a}$ & $410.56 \pm 8.02 \times 291.05 \pm 5.08^{a}$ & $36.85 \pm 0.62^{a}$ \\
\hline
\end{tabular}

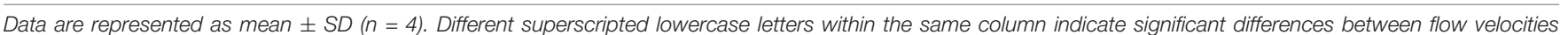
$(P<0.05)$.

TABLE 4 | Biochemical content of $H$. discus hannai larvae, reared under different flow velocities.

\begin{tabular}{|c|c|c|c|c|c|}
\hline \multirow[t]{2}{*}{ Variable } & \multicolumn{5}{|c|}{ Flow velocity } \\
\hline & $0 \mathrm{~L} / \mathrm{h}$ & $5 \mathrm{~L} / \mathrm{h}$ & $10 \mathrm{~L} / \mathrm{h}$ & $20 \mathrm{~L} / \mathrm{h}$ & 40 L/h \\
\hline Protein content (g/L) & $0.98 \pm 0.05^{a}$ & $1.06 \pm 0.05^{a}$ & $1.01 \pm 0.08^{a}$ & $0.97 \pm 0.07^{a}$ & $1.04 \pm 0.07^{a}$ \\
\hline Lactic acid content (mmol/g prot) & $0.076 \pm 0.008^{b}$ & $0.072 \pm 0.006^{b}$ & $0.078 \pm 0.006^{b}$ & $0.089 \pm 0.007^{a b}$ & $0.107 \pm 0.010^{a}$ \\
\hline Triglyceride (mmol/g prot) & $0.83 \pm 0.04^{b}$ & $0.90 \pm 0.07^{a}$ & $0.88 \pm 0.05^{a}$ & $0.69 \pm 0.07^{c}$ & $0.80 \pm 0.02^{b}$ \\
\hline ATP ( $\mu \mathrm{mol} / \mathrm{g}$ prot) & $229.38 \pm 9.62^{b}$ & $192.07 \pm 7.33^{\mathrm{C}}$ & $199.44 \pm 7.06^{c}$ & $263.56 \pm 8.65^{\mathrm{a}}$ & $277.05 \pm 5.93^{a}$ \\
\hline Glycogen (mg/g) & $1.22 \pm 0.04^{a}$ & $1.13 \pm 0.08^{a}$ & $1.25 \pm 0.02^{\mathrm{a}}$ & $1.17 \pm 0.04^{\mathrm{a}}$ & $0.83 \pm 0.06^{b}$ \\
\hline
\end{tabular}

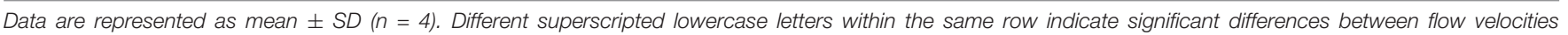
$(P<0.05)$.

\section{Metabolic Enzyme Activity}

Larval HK activity varied significantly at different velocities, gradually increasing with increasing flow velocity (Table 5). Larval HK activity in the $40 \mathrm{~L} / \mathrm{h}$ group was significantly higher than in any other group $(P<0.05)$. The PK activity also followed a similar pattern, peaking in the $40 \mathrm{~L} / \mathrm{h}$ group but not being significantly different across any other group. At $20 \mathrm{~L} / \mathrm{h}$, the larval SDH and MDH activities peaked, and then dropped significantly when the velocity increased to $40 \mathrm{~L} / \mathrm{h}(P<0.05)$. By contrast, the larval SDH activity in the $40 \mathrm{~L} / \mathrm{h}$ group was significantly higher than in the 0,5 , and $10 \mathrm{~L} / \mathrm{h}$ groups $(P<0.05)$. Flow velocity also had significant effects on larval LDH activity, which was significantly higher in the $40 \mathrm{~L} / \mathrm{h}$ group compared with any other group $(P<0.05)$, although no significant differences were identified among the other velocity groups.

\section{Gene Expression}

The expression levels of IGFBP7 varied significantly at different flow velocities, being significantly higher in the $10 \mathrm{~L} / \mathrm{h}$ group than in the $40 \mathrm{~L} / \mathrm{h}$ group, with no significant differences identified compared with any other velocity group (Figure 3, $P>0.05$ ). No significant difference was identified in the expression levels of $a 2 A D R$ between the 5,10 , and $20 \mathrm{~L} / \mathrm{h}$ groups, although its expression levels in all three groups were significantly higher than in either the 0 or $40 \mathrm{~L} / \mathrm{h}$ groups $(P<0.05)$.

\section{DISCUSSION}

Most marine invertebrates have a planktonic life-history stage, which can persist for an extended period of time until the most suitable substrate is found; thus, settlement by invertebrate larvae is seen as a passive delivery process to the surface (Abelson and Denny, 1997) with an active behavioral component once at the surface and possible active components in the water column (Harvey and Bourget, 1997; Walters et al., 1999). Thus, hydrodynamic force is also considered to be an external factor impacting larval settlement (Welch et al., 1999). Abalones reside on the bottom of coral reefs or in rock cracks. Their larvae usually adhere to the uneven sand surface, where the sedimentation process will be always affected by the flow of seawater (Boxshall, 2000; Wassnig et al., 2010). During aquacultural rearing, stable water flows avoid fertilized eggs from densely accumulating in particular areas of the rearing pond (Wu and Zhang, 2013). Thus, in the current study, five sets of recirculating water systems suitable for dense rearing of larvae were designed that not only simulated various water flow states, but also maintained a stable water temperature and salinity level. The larval hatching and survival rate in the recirculating water system were higher than in traditional still water rearing systems. With water quality indicators monitored, no significant differences in dissolved oxygen, $\mathrm{NO}_{2}-\mathrm{N}$, and $\mathrm{NO}_{3}-$ $\mathrm{N}$ concentrations under the recirculating water systems were found among the groups. The concentration of TAN-N and $\mathrm{NO}_{2}-$ $\mathrm{N}$ in the control group was significantly higher than in each velocity group. In still water aquaculture systems, some dead eggs and larvae are likely to accumulate, which could provide a natural medium for the growth of bacteria; and dead larvae would also lead to a higher concentration of TAN-N and $\mathrm{NO}_{2}-$ $\mathrm{N}$ in still water as a result of bacterial decomposition. In the recirculating aquaculture system, the measures taken to clean the filter cotton and add a UV disinfection lamp not only removed water contaminants to prevent the water quality from deterioration, but also suppressed the proliferation of harmful 
TABLE 5 | Effect of flow velocity on the activity of metabolic enzymes of $H$. discus hannai larvae.

\begin{tabular}{|c|c|c|c|c|c|}
\hline \multirow[t]{2}{*}{ Variable } & \multicolumn{5}{|c|}{ Flow velocity } \\
\hline & $0 \mathrm{~L} / \mathrm{h}$ & $5 \mathrm{~L} / \mathrm{h}$ & $10 \mathrm{~L} / \mathrm{h}$ & $20 \mathrm{~L} / \mathrm{h}$ & $40 \mathrm{~L} / \mathrm{h}$ \\
\hline Hexokinase (HK) (U/g prot) & $12.17 \pm 0.51^{\mathrm{c}}$ & $11.11 \pm 0.37^{\mathrm{C}}$ & $10.08 \pm 0.48^{c}$ & $14.89 \pm 0.26^{b}$ & $18.89 \pm 0.64^{a}$ \\
\hline Pyruvate kinase (PK) (U/g prot) & $7.15 \pm 0.42^{b}$ & $7.24 \pm 0.22^{b}$ & $6.99 \pm 0.41^{b}$ & $7.07 \pm 0.53^{b}$ & $9.93 \pm 0.32^{a}$ \\
\hline Succinate dehydrogenase (SDH) (U/mg prot) & $3.38 \pm 0.21^{\mathrm{c}}$ & $4.02 \pm 0.34^{\mathrm{c}}$ & $3.79 \pm 0.27^{c}$ & $6.81 \pm 0.19^{a}$ & $5.07 \pm 0.24^{b}$ \\
\hline Malate dehydrogenase (MDH) (U/mg prot) & $8.02 \pm 0.73^{b}$ & $7.62 \pm 0.55^{b}$ & $7.27 \pm 0.40^{b}$ & $9.15 \pm 0.37^{\mathrm{a}}$ & $7.94 \pm 0.53^{b}$ \\
\hline Lactate dehydrogenase (LDH) (U/g prot) & $2.45 \pm 0.19^{b}$ & $2.92 \pm 0.28^{b}$ & $2.07 \pm 0.15^{\mathrm{b}}$ & $3.15 \pm 0.18^{b}$ & $5.47 \pm 0.14^{a}$ \\
\hline
\end{tabular}

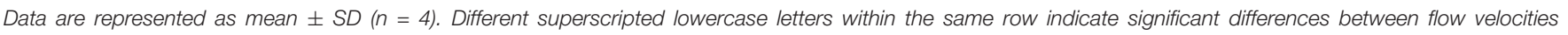
$(P<0.05)$.

bacteria to maintain a stable aquaculture water quality. In water, $\mathrm{NO}_{2}-\mathrm{N}$ is an intermediate product of ammonia nitrification resulting from the breakdown of aquatic organisms. Its ongoing accumulation in water impacts the physiological conditions of rearing organisms and can suppress their growth, resulting in higher mortality (Harris et al., 1998). The concentration of $\mathrm{NO}_{2}$ $\mathrm{N}$ in each group did not exceed $0.1 \mathrm{mg} / \mathrm{L}$, a level within the normal safe concentration tolerance of abalone (Kim et al., 2000); however, the decomposition products from dead larvae could not be readily removed, even though the cyclic accumulation in water is one of the crucial factors resulting in higher concentrations
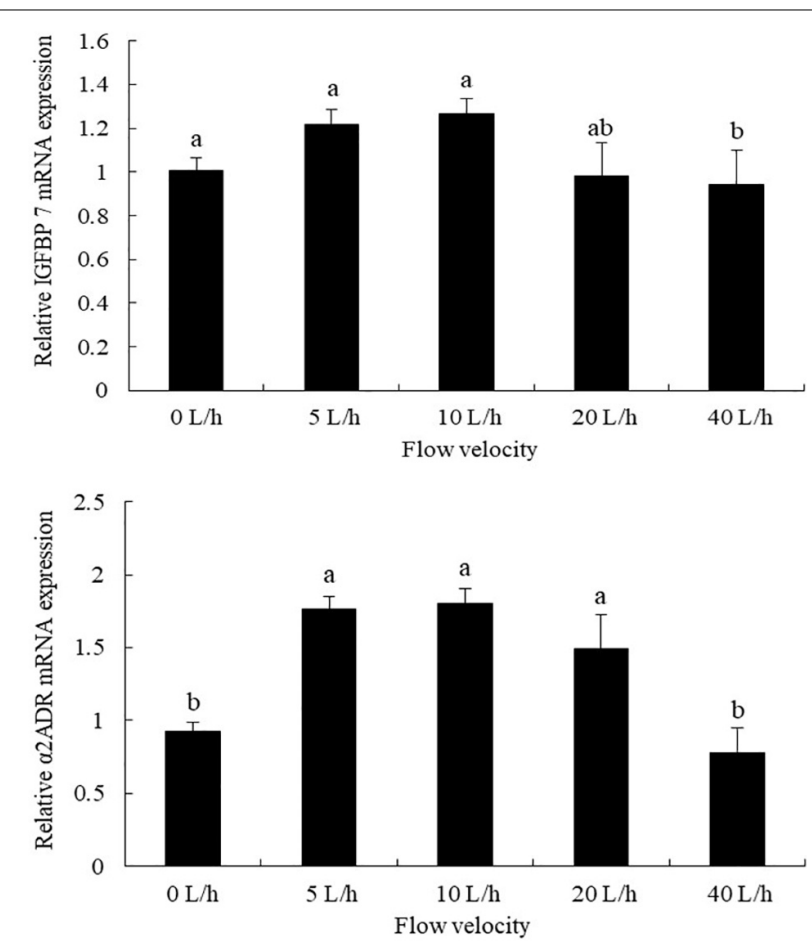

FIGURE 3 | Effects of flow velocity on the relative expression of /GFBP7 (insulin-like growth factor binding protein 7) and $\alpha 2 A D R$ ( $\alpha 2$-Adrenoceptor) in Pacific abalone $H$. discus hannai larvae. Values are means and standard deviation of four replicates (means $\pm S D ; n=4$ ). Significant variations were found by one-way analysis of variance, $P<0.05$, followed by Tukey test. Different letters denote significant differences between flow velocities. of $\mathrm{NO}_{2}-\mathrm{N}$ and lower larval hatching and survival rates in the control group.

The size upon completion of larval shell development and at metamorphosis in the 20 and $40 \mathrm{~L} / \mathrm{h}$ groups were significantly higher than in any other group, but the metamorphosis and survival rates were decreased. Such an extended planktonic period could cause larvae to use more yolk nutrition for their growth, resulting in a greater size at larval metamorphosis. The energy available for larvae would reduce during metamorphosis, resulting in a decline of metamorphosis rate. In addition, the flow velocity at $20 \mathrm{~L} / \mathrm{h}$ and $40 \mathrm{~L} / \mathrm{h}$ might also cause stress to larvae. Thus, some energy would be used to resist such an unfavorable environment, further reducing the energy available for metamorphosis. Previous research showed that an extended planktonic stage leads to adverse effects on the survival and growth of juvenile mollusks (Pechenik and Rice, 2001; Huchette et al., 2003). Especially for larval abalone, which rely on yolk nutrition, an extended planktonic stage would deplete yolk nutrients, resulting in declining survival and growth rates of juvenile abalone (Marshall, 2008; Dineshram et al., 2013). Given that the culture water was not subject to disturbance before larval hatching in the control group, a lack of water flow could lead to a higher likelihood of mutual adhesion of fertilized eggs. Under the microscope, normally developed eggs adhering to dead eggs were observed in the control group. During adhesion, the increased mucus secretions will also impact normally developed fertilized eggs nearby, causing the larval hatching and survival rates in the control group to be significantly lower than in the recirculating water groups. It was also noted that the higher velocity was accompanied by a lower larval hatching rate and higher deformity rate. A possible reason is that the rapid water flow interferes with the normal development of fertilized eggs, impeding the formation of the ciliary band and increasing the deformity rate. Overly high velocity might also impact the formation of veliger larvae and cilia movement. Once the autonomous movement of larvae is completely altered as a response to the impact from high velocity, the energy stored in larvae would be gradually consumed, eventually leading to higher mortality. Thus, the flow velocity should be selected so that fertilized eggs would be evenly distributed as possible; larvae would then be able to move autonomously with the lowest-possible energy expenditure through the water, enabling more energy to be derived from the yolk nutrition for metamorphosis. 
Although animals can acquire energy from the decomposition of various energy substances, most energy sources come from the consumption of protein, fat, and carbohydrates (Lauff and Wood, 1997; Kieffer et al., 1998; Weber, 2011). Larval attachment and metamorphosis both require abundant energy, most of which comes from the yolk nutrients (Roberts et al., 2001). The content of TG in larvae in the $20 \mathrm{~L} / \mathrm{h}$ group was significantly lower than that in any other velocity group, suggesting that this higher velocity leads to higher energy demands of larvae. However, no significant difference was identified in the TG content between the control and $40 \mathrm{~L} / \mathrm{h}$ groups, although the glycogen content in the latter was significantly lower than in the former, suggesting that energy sources delivered to larvae came from the conversion of TG to glycogen after the flow velocity increased. No significant difference was found in the protein content among the groups, suggesting that larvae had not utilized energy in the form of protein metabolism. Previous work revealed that shrimps make use of carbohydrates and TGs in different amounts. Li et al. (2019) found that at $3 \mathrm{~cm} / \mathrm{s}$, Fenneropenaeus chinensis depends on energy delivered from the decomposition of TG in muscles; at a velocity over $3 \mathrm{~cm} / \mathrm{s}$, the glycogen in muscles begins to be used as the primary substance for energy delivery, which is associated with the oxygen supply. Compared with glycogen, TG has a higher calorific value and can release more energy after following complete oxidation and decomposition (Livesey and Elia, 1988). In the current study, no significant difference was found in the dissolved oxygen concentration among the velocity groups. However, when the velocity increased to $40 \mathrm{~L} / \mathrm{h}$, the water flow impact might deprive the larvae from having control of their own movement. While resisting the water flow, a drastic increase in oxygen consumption might be a limiting factor to their growth. Compared with fat, glycogen would consume less oxygen for the production of ATP with the same molecular weight (Li et al., 2015). Thus, the energy available to larvae in the $40 \mathrm{~L} / \mathrm{h}$ group is likely to have come from the conversion of TG to glycogen. At this velocity, the content of glycogen was significantly reduced compared with the $20 \mathrm{~L} / \mathrm{h}$ group. Despite an increase in ATP content, the energy from the decomposition of glycogen might not satisfy the energy needs of larvae to cope with the impact of the increased water flow.

The energy metabolism balance of aquatic organisms can be negatively affected by the external and nutritional environment, given that they might require extra energy to relieve such stress (Boeck et al., 2006; Xu et al., 2015, 2016). Intensified sugar metabolism is a regular response to stress. Hexokinase and pyruvate kinase are the key rate-limiting enzymes in glycolysis, and variation in their activity has a significant role in regulating sugar metabolism, indicating the level of glycolysis (Van Aardt and Wolmarans, 1987). In the $40 \mathrm{~L} / \mathrm{h}$ group, the HK and PK activity was significantly higher than in any other group, with the activity of HK gradually increasing with the flow velocity, suggesting that larvae produced more energy by increasing glycolysis. A higher rate of glycolysis facilitates the production of ATP and improves tolerance against stress (Laiz-Carrión et al., 2002). Gao et al. (2017) found that, as salinity decreased from 30 to $20 \%$, the activity of HK and PK in the liver of H. discus hannai increased; under a low salinity level, the liver accelerated the phosphorylation of glucose to promote glucose transformation and speed up glycolysis, thereby delivering energy to the tissues. $\mathrm{SDH}$ is the only enzyme embedded in the inner membrane of mitochondria in the TCA cycle. Oxaloacetate, as the product catalyzed by malate dehydrogenase, is one of the initiators of the TCA cycle. To a certain extent, two kinds of enzyme can represent the rate of the TCA cycle and the level of aerobic metabolism (Lussey-Lepoutre et al., 2015; Akila et al., 2016). Panepucci et al. (2000) reported that MDH acts as a carbon source and provides oxaloacetate for the TCA cycle, resulting in an additional 32 ATP molecules per glucose molecule oxidized. In the current study, the activity of SDH and MDH in the $20 \mathrm{~L} / \mathrm{h}$ group was significantly higher than in any other group, whereas the ATP content in this group was also significantly higher than in the 0,5 , and $10 \mathrm{~L} / \mathrm{h}$ groups. When the velocity increased to $40 \mathrm{~L} / \mathrm{h}$, the activity of SDH and MDH decreased significantly, suggesting that the activity of the TCA cycle was also reduced and aerobic metabolism suppressed. At this point, the activity of LDH significantly increase and the lactic acid content also peaked, implying that the energy delivery began to switch from aerobic to anaerobic metabolism, with the latter becoming the primary energy source for the larvae. Exposure of Litopenaeus vannamei to moderate hypoxia resulted in the accumulation of lactic acid and higher glucose content in hemolymph and muscle tissues, suggesting that anaerobic metabolism was increased (SoñanezOrganis et al., 2010). As a crucial glycolytic enzyme, lactate dehydrogenase appears to be more important when larvae need extra energy under stress (Gao et al., 2018). Especially in the $40 \mathrm{~L} / \mathrm{h}$ group, an increase in the activity of lactate dehydrogenase caused the ATP content of larvae to peak. At this point, the content of glycogen further decreased, suggesting that the energy demand had increased in response to the high velocity; larvae began to utilize anaerobic metabolism to release more energy to satisfy the increased energy demand. As the direct supplier of biological energy, ATP is the main indicator of biological activity. When the salinity dropped suddenly from 56 to $52 \%$ and $48 \%$, the ATP content increased significantly in L. vannamei, suggesting that an extra energy supply was needed under the sudden change in salinity, thereby releasing a large amount of ATP (Shen et al., 2020). Once excessively accumulated, lactic acid as the by-product of anaerobic glycolysis would not only maintain the activity of glycolytic enzymes at a lower level, but also damage organs and tissues (Brizel et al., 2001; Zenteno-Savín et al., 2006). In the current study, as lactic acid increased, the larval survival rate in $40 \mathrm{~L} / \mathrm{h}$ was significantly lower than that any other group, suggesting the accumulation of lactic acid adversely impacted the survival of the larvae.

Insulin-like growth factor binding protein 7 (IGFBP7) is a member of the IGFBP family. Overexpression of IGFBP7 in the MDA-MB-468 cell line significantly suppressed cell growth. IGFBP7 can also prevent the phosphorylation of mitogen-activated protein kinase (MAPK) ERK-1/2, resulting in weakening of the pathway signal, suggesting that IGFBP7 regulates cell growth by affecting this signaling pathway (Amemiya et al., 2011). IGFBP7 has biological functions and expression patterns that depend upon the diversity of cell types, which regulate cell growth and proliferation both positively and 
negatively (Hwa et al., 1999). During the metamorphosis of Haliotis diversicolor, larvae shed the velum, the gills and feet gradually grow in size, and peristomal shell formation begins (Bishop et al., 2006; Heyland and Moroz, 2006). During the early larval period, saIGFBP7 can promote the transition of larvae from a planktonic state to benthic life by upregulating the expression of growth-related genes and hormones (Wang et al., 2015). Wang et al. (2016) found that IGFBP7 was engaged in the proliferation and differentiation of the mantle and foot cells of $H$. diversicolor. When the expression levels of IGFBP7 were altered, the larval mortality rate significantly increased, whereas the settlement rate significantly dropped over $4 \mathrm{~h}$. In the current study, the expression levels of IGFBP7 in the $40 \mathrm{~L} / \mathrm{h}$ group decreased significantly, as did the larval metamorphosis rate, suggesting that larval development can be predicted based on changes in the expression levels of IGFBP7; a longer planktonic duration would reduce the nutrients available from the yolk, and the energy ultimately required for the completion of metamorphosis. Thus, an appropriate of flow velocity range would be essential for the synchronous and rapid completion of larval metamorphosis in this species.

Numerous neurotransmitters are involved in the metamorphosis of larval shellfish. For example, Coon and Bonar (1987) found that alpha 1-adrenoceptor is involved in the metamorphosis of Crassostrea gigas. Epinephrine has been proven to induce the larval metamorphosis of Venerupis pullastra and Ruditapes philippinarum (García-Lavandeira et al., 2005). In research related to Crassostrea angulate, epinephrine was found to induce metamorphosis and alpha 1-adrenoceptor had higher expression levels (Yang et al., 2012). In the current study, the expression levels of $\alpha 2 A D R$ in the 0 and $40 \mathrm{~L} / \mathrm{h}$ groups were significantly lower than in any other group, suggesting that flow velocity had significant effects on larval metamorphosis; the larval metamorphosis rate was higher at more appropriate velocities ( 5 and $10 \mathrm{~L} / \mathrm{h}$ ), whereas the expression levels of $a 2 A D R$ in the 5 and $10 \mathrm{~L} / \mathrm{h}$ group were also significantly higher than in the 0 and $40 \mathrm{~L} / \mathrm{h}$ groups, suggesting that the expression levels of $a 2 A D R$ are closely associated with larval metamorphosis. In the 5 and $10 \mathrm{~L} / \mathrm{h}$ groups, the time required for larval metamorphosis shortened significantly, suggesting that the larvae would be less likely to consume all the yolk nutrients and would also face a reduced risk from any abrupt changes in the environment that might occur during metamorphosis, compared with if the period of metamorphosis was extended.

In the current study, the larval hatching rate, survival rate, and metamorphosis rate increased when the flow velocity was kept to $5-10 \mathrm{~L} / \mathrm{h}$. In the control group, a lack of water flow before larvae developed to the trochophore stage led to the mutual adhesion of fertilized eggs and their local accumulation; when dead eggs were recorded, the water quality also deteriorated, and the higher concentration of TAN and $\mathrm{NO}_{2}-\mathrm{N}$ might be the main reason for the lower survival rate of the larvae. Larval density can be reduced to avoid their accumulation, but the presence of unfertilized eggs and dead larvae consistently impacts the stability of the aquaculture water environment, in that no water is exchanged before larval metamorphosis in conventional aquaculture systems. When the flow velocity increased to $40 \mathrm{~L} / \mathrm{h}$, despite the increase in the dissolved oxygen concentration and the decrease in TAN concentration, the impact of this rapid flow switched the mode of larval energy metabolism from aerobic to anaerobic metabolism, and the primary source of energy also shifted from TG to glycogen. Under these circumstances, the planktonic stage of larvae was prolonged and more energy was consumed, eventually reducing the amount of energy available for completion of metamorphosis and, thus, the larval metamorphosis rate. Therefore, future upflow larval rearing systems could be designed for $H$. discus hannai that maintain the quality of the rearing water and the velocity range at 5$10 \mathrm{~L} / \mathrm{h}$, which would not only reduce the adhesion of fertilized eggs and dead eggs and the energy consumption of larvae during metamorphosis, but also increase the larval metamorphosis rate and synchronization of metamorphosis, improving the aquaculture of this species as well as our understanding of its larval development.

\section{DATA AVAILABILITY STATEMENT}

All data generated or analyzed in this study are included in this published article.

\section{ETHICS STATEMENT}

This animal study was reviewed and approved by the Animal Welfare Committee of the College of Ocean \& Earth Sciences, Xiamen University (permit no. COES-0001).

\section{AUTHOR CONTRIBUTIONS}

WY and XG conceptualized the study. MZ, ML, and SL conducted research and collected the data. XL and WY provided the materials and interpreted the data. $\mathrm{MZ}$ and $\mathrm{XG}$ wrote the manuscript. WY and CK had primary responsibility for the final content. All authors read and approved the final manuscript.

\section{FUNDING}

This research was supported by grants from the Chinese Ministry of Science and Technology through the Fujian Key S\&T Project (No. 2020NZ08003 and 2019N0001), the Fujian Marine Economic Development Fund Project (FJHJF-L-2020-7), and Earmarked fund for the Modern Agro-industry Technology Research System (CARS-49).

\section{ACKNOWLEDGMENTS}

We would like to thank Chengyun Li and Jianxiong Li for their assistance with abalone collection and rearing. 


\section{REFERENCES}

Abelson, A., and Denny, M. (1997). Settlement of marine organisms in flow. Annu. Rev. Ecol. Evol. Syst. 28, 317-339. doi: 10.1146/ANNUREV.ECOLSYS.28.1.317

Akila, P., Asaikumar, L., and Vennila, L. (2016). Chlorogenic acid ameliorates isoproterenol-induced myocardial injury in rats by stabilizing mitochondrial and lysosomal enzymes. Biomed. Pharmacother. 85, 582-591. doi: 10.1016/j. biopha.2016.11.067

Amemiya, Y., Yang, W., Benatar, T., Nofech-Mozes, S., Yee, A., Kahn, H., et al. (2011). Insulin like growth factor binding protein-7 reduces growth of human breast cancer cells and xenografted tumors. Breast Cancer Res. Treat. 126, 373-384. doi: 10.1007/s10549-010-0921-0

Bao, J., Li, X., Yu, H., and Jiang, H. (2018). Respiratory metabolism responses of Chinese mitten crab, Eriocheir sinensis and Chinese grass shrimp, Palaemonetes sinensis, subjected to environmental hypoxia stress. Front. Physiol. 9:1559. doi: 10.3389/fphys.2018.01559

Bishop, C. D., Erezyilmaz, D. F., Flatt, T., Georgiou, C. D., Hadfield, M. G., Heyland, A., et al. (2006). What is metamorphosis? Integr. Comp. Biol. 46, 655-661. doi: 10.1093/icb/icl004

Boeck, G. D., Ven, K. V. D., Hattink, J., and Blust, R. (2006). Swimming performance and energy metabolism of rainbow trout, common carp and gibel carp respond differently to sublethal copper exposure. Aquat. Toxicol. 80, 92-100. doi: 10.1016/j.aquatox.2006.07.017

Boxshall, A. J. (2000). The importance of flow and settlement cues to larvae of the abalone, Haliotis rufescens Swainson. J. Exp. Mar. Biol. Ecol. 254, 143-167. doi: 10.1016/S0022-0981(00)00274-4

Brizel, D. M., Schroeder, T., Scher, R. L., Walenta, S., Clough, R. W., Dewhirst, M. W., et al. (2001). Elevated tumor lactate concentrations predict for an increased risk of metastases in head-and-neck cancer. Int. J. Radiat. Oncol. 51, 349-353. doi: 10.1016/s0360-3016(01)01630-3

China Bureau of Fisheries (2021). China Fisheries Yearbook in 2020. Beijing: Agricultural Press of China.

Coon, S. L., and Bonar, D. B. (1987). Pharmacological evidence that alpha ${ }^{-}$ adrenoceptors mediate metamorphosis of the Pacific oyster, Crassostrea gigas. Neurosciece 23, 1169-1174. doi: 10.1016/0306-4522(87)90190-4

Dineshram, R., Thiyagarajan, V., Lane, A., Yu, Z., Shu, X., and Leung, P. T. Y. (2013). Elevated $\mathrm{CO}_{2}$ alters larval proteome and its phosphorylation status in the commercial oyster, Crassostrea hongkongensis. Mar. Biol. 160, 2189-2205. doi: 10.1007/s00227-013-2176-x

Dong, W., Liu, Z., Qiu, L., Wang, W., Song, X., Wang, X., et al. (2017). The modulation role of serotonin in Pacific oyster Crassostrea gigas in response to air exposure. Fish Shellfish Immun. 62, 341-348. doi: 10.1016/j.fsi.2017. 01.043

Ebert, E. E., and Houk, J. L. (1984). Elements and innovations in the cultivation of red abalone Haliotis rufescens. Aquaculture 39, 375-392. doi: 10.1016/00448486(84)90279-5

Friedrich, C. G. (1998). Physiology and genetics of sulfur-oxidizing bacteria. $A d v$. Microb. Physiol. 39, 235-289. doi: 10.1016/s0065-2911(08)60018-1

Gao, X., Li, X., Shi, C., Wu, F., Song, C., and Liu, Y. (2018). Effects of stocking density on growth, metabolism, and energy budget of Haliotis discus hannai Ino. Aquaculture 483, 84-95. doi: 10.1016/j.aquaculture.2017.09.045

Gao, X., Li, Y., Li, X., Wu, F., Song, C., and Liu, Y. (2017). The response and osmotic pressure regulation mechanism of Haliotis discus hannai (Mollusca. Gastropoda) to sudden salinity changes. Hydrobiologia 795, 181-198. doi: 10. 1007/s10750-017-3129-z

Gao, X., Zhang, M., Li, X., Song, C., and Liu, Y. (2016). Effects of light quality and intensity on the growth, survival and metamorphosis of Haliotis discus hannai Ino larvae. Aquac. Res. 48, 1-14. doi: 10.1111/are.13164

García-Lavandeira, M., Silva, A., Abad, M., Pazos, A. J., Sánchez, J. L., and PérezParallé, M. L. (2005). Effects of GABA and epinephrine on the settlement and metamorphosis of the larvae of four species of bivalve molluscs. J. Exp. Mar. Biol. Ecol. 316, 149-156. doi: 10.1016/j.jembe.2004.10.011

Harris, J. O., Maguire, G. B., Edwards, S., and Hindrum, S. M. (1998). Effect of ammonia on growth rate and oxygen consumption of juvenile greenlip abalone, Haliotis laevigata donovan. Aquaculture 160, 259-272. doi: 10.1016/S00448486(97)00249-4

Harvey, M., and Bourget, E. (1997). Recruitment of marine invertebrates onto arborescent epibenthic structures: active and passive processes acting at different spatial scales. Mar. Ecol. Prog. Ser. 153, 203-215. doi: 10.3354/ meps 153203

Heinrichs-Caldas, W., Campos, D. F., Paula-Silva, M. N., and Almeida-Val, V. M. F. (2019). Oxygen-dependent distinct expression of hif- $1 \alpha$ gene in aerobic and anaerobic tissues of the Amazon Oscar, Astronotus crassipinnis. Comp. Biochem. Phys. B 227, 31-38. doi: 10.1016/j.cbpb.2018.08.011

Heyland, A., and Moroz, L. L. (2006). Signaling mechanisms underlying metamorphic transitions in animals. Integr. Comp. Biol. 46, 743-759. doi: 10. 1093/icb/icl023

Huchette, S. M. H., Koh, C. S., and Day, R. W. (2003). The effects of density on the behaviour and growth of juvenile blacklip abalone (Haliotis rubra). Aquacult. Int. 11, 411-428. doi: 10.1023/B:AQUI.0000004194.85299.38

Hwa, V., Oh, Y., and Rosenfeld, R. G. (1999). The insulin-like growth factorbinding protein (IGFBP) superfamily. Endocr. Rev. 20, 761-787. doi: 10.1210/ edrv.20.6.0382

Ivanina, A. V., Froelich, B., Williams, T., Sokolov, E. P., Oliver, J. D., and Sokolova, I. M. (2011). Interactive effects of cadmium and hypoxia on metabolic responses and bacterial loads of eastern oysters Crassostrea virginica Gmelin. Chemosphere 82, 377-389. doi: 10.1016/j.chemosphere.2010.09.075

Kieffer, J. D., Alsop, D., and Wood, C. M. (1998). A respirometric analysis of fuel use during aerobic swimming at different temperatures in rainbow trout (Oncorhynchus mykiss). J. Exp. Biol. 201, 3123-3133. doi: 10.1242/jeb.201.22. 3123

Kim, S. K., Kong, I., Lee, B. H., Kang, L., Lee, M. G., and Suh, K. H. (2000). Removal of ammonium-N from a recirculation aquacultural system using an immobilized nitrifier. Aquacult. Eng. 21, 139-150. doi: 10.1016/S0144-8609(99) 00026-6

Laiz-Carrión, R., Sangiao-Alvarellos, S., Guzmán, J. M., Martín del Río, M. P., Míguez, J. M., Soengas, J. L., et al. (2002). Energy metabolism in fish tissues related to osmoregulation and cortisol action. Fish Physiol. Biochem. 27, 179188. doi: 10.1023/B:FISH.0000032725.96481.b8

Lauff, R. F., and Wood, C. M. (1997). Effects of training on respiratory gas exchange, nitrogenous waste excretion, and fuel usage during aerobic swimming in juvenile rainbow trout (Oncorhynchus mykiss). Can. J. Fish Aquat. Sci. 54, 566-571. doi: 10.1139/cjfas-54-3-566

Li, D., Wei, X., Lin, X., Xu, Z., and Mu, X. (2015). Effects of exercise training on carbohydrate and lipid catabolism in the swimming muscles of Nile tilapia (Oreochromis niloticus). J. Anim. Physiol. Anim. Nutr. 99, 893-898. doi: 10.1111/ jpn. 12300

Li, J., Xu, X., Li, W., and Zhang, X. (2019). Behavioural and physiological responses to low-and high-intensity locomotion in Chinese shrimp Fenneropenaeus chinensis. J. Comp. Physiol. A Neuroethol. Sens. Neural Behav. Physiol. 205, 87-102. doi: 10.1007/s00359-018-1306-9

Livesey, G., and Elia, M. (1988). Estimation of energy expenditure, net carbohydrate utilization, and net fat oxidation and synthesis by indirect calorimetry: evaluation of errors with special reference to the detailed composition of fuels. Am. J. Clin. Nutr. 47, 608-628. doi: 10.1093/ajcn/47.4.608

López-Patiño, M. A., Hernández-Pérez, J., Gesto, M., Librán-Pérez, M., Míguez, J. M., and Soengas, J. L. (2014). Short-term time course of liver metabolic response to acute handling stress in rainbow trout, Oncorhynchus mykiss. Comp. Biochem. Phys. A Mol. Integr. Physiol. 168, 40-49. doi: 10.1016/j.cbpa.2013.10. 027

Lucas, M. I., Walker, G., Holland, D. L., and Crisp, D. J. (1979). An energy budget for the free-swimming and metamorphosing larvae of Balanus balanoides (Crustacea: Cirripedia). Mar. Biol. 55, 221-229. doi: 10.1007/BF00396822

Lussey-Lepoutre, C., Bellucci, A., Morin, A., Buffet, A., Amar, L., Janin, M., et al. (2015). In vivo detection of succinate by magnetic resonance spectroscopy as a hallmark of $S D H x$ mutations in paraganglioma. Clin. Cancer Res. 22, 1120-1129. doi: 10.1158/1078-0432.CCR-15-1576

Maldonado, M., and Young, C. M. (1999). Effects of the duration of larval life on postlarval stages of the demosponge Sigmadocia caerulea. J. Exp. Mar. Biol. Ecol. 232, 9-21. doi: 10.1016/S0022-0981(98)00076-8

Manahan, D. T., and Crisp, D. J. (1983). Autoradiographic studies on the uptake of dissolved amino acids from sea water by bivalve larvae. J. Mar. Biol. Assoc. U.K. 63, 673-682. doi: 10.1017/S0025315400070983

Marshall, D. J. (2008). Transgenerational plasticity in the sea: context-dependent maternal effects across the life history. Ecology 89, 418-427. doi: 10.1890/070449.1 
Marshall, D. J., Pechenik, J. A., and Keough, M. J. (2003). Larval activity levels and delayed metamorphosis affect post-larval performance in the colonial, ascidian Diplosoma listerianum. Mar. Ecol. Prog. Ser. 246, 153-162. doi: 10. 3354/meps 246153

Natalia, Y., Hashim, R., Ali, A., and Chong, A. (2004). Characterization of digestive enzymes in a carnivorous ornamental fish, the Asian bony tongue Scleropages formosus (Osteoglossidae). Aquaculture 233, 305-320. doi: 10.1016/ j.aquaculture.2003.08.012

Panepucci, L., Fernandes, M. N., Sanches, J. R., and Rantin, F. T. (2000). Changes in lactate dehydrogenase and malate dehydrogenase activities during hypoxia and after temperature acclimation in the armored fish, Rhinelepis strigose (siluriformes, loricariidae). Rev. Brasil. Biol. 60, 353-360. doi: 10.1590/ S003471082000000200021

Pechenik, J. A., and Rice, M. E. (2001). Influence of delayed metamorphosis on post settlement survival and growth in the sipunculan Apionsoma misakianum. Invertebr. Biol. 120, 50-57. doi: 10.2307/3227225

Reyes-Ramos, C. A., Peregrino-Uriarte, A. B., Cota-Ruiz, K., ValenzuelaSoto, E. M., Leyva-Carrillo, L. L., and Yepiz-Plascencia, G. (2018). Phosphoenolpyruvate carboxykinase cytosolic and mitochondrial isoforms are expressed and active during hypoxia in the white shrimp Litopenaeus vannamei. Comp. Biochem. Phys. B Biochem. Mol. Biol. 226, 1-9. doi: 10.1016/j.cbpb.2018. 08.001

Roberts, R. D., Lapworth, C., and Barker, R. J. (2001). Effect of starvation on the growth and survival of post-larval abalone (Haliotis iris). Aquaculture 200, 323-338. doi: 10.1016/S0044-8486(01)00531-2

Shen, M., Cui, Y., Wang, R., Dong, T., Ye, H., Wang, S., et al. (2020). Acute response of Pacific white shrimp Litopenaeus vannamei to high-salinity reductions in osmosis-, metabolism-, and immune-related enzyme activities. Aquacult. Int. 28, 31-39. doi: 10.1007/s10499-019-00441-y

Shilling, F. M., and Manahan, D. T. (1990). Energetics of early development for the sea urchins Strongylocentrotus purpuratus and Lytechinus pictus and the crustacean Artemia sp. Mar. Biol. 106, 119-127. doi: 10.1007/BF02114682

Shilling, F. M., Hoegh-Guldberg, O., and Manahan, D. T. (1996). Sources of energy for increased metabolic demand during metamorphosis of the abalone Haliotis rufescens (mollusca). Biol. Bull U.S. 191, 402-412. doi: 10.2307/1543013

Soñanez-Organis, J. G., Racotta, I. S., and Yepiz-Plascencia, G. (2010). Silencing of the hypoxia induciblefactor 1-HIF-1-obliterates the effects of hypoxia on glucose and lactate concentrations in a tissue-specific manner in the shrimp Litopenaeus vannamei. J. Exp. Mar. Biol. Ecol. 393, 51-58. doi: 10.1016/j.jembe. 2010.06.031

Thiyagarajan, V., Pechenik, J. A., Gosselin, L. A., and Qian, P. Y. (2007). Juvenile growth in barnacles: combined effect of delayed metamorphosis and sub-lethal exposure of cyprids to low-salinity stress. Mar. Ecol. Prog. Ser. 344, 173-184. doi: 10.3354/meps06931

Van Aardt, W. J., and Wolmarans, C. T. (1987). Effects of anoxia on the haemolymph physiology and lactate concentrations in the freshwater crab Potamon warreni calman. Comp. Biochem. Physiol. 88, 671-675. doi: 10.1016/ 0300-9629(87)90681-5

Vicose, G. C. D., Viera, M. P., Bilbao, A., and Izquierdo, M. S. (2007). Embryonic and larval development of Haliotis tuberculate coccinea Reeve: an indexed micro-photographic sequence. J. Shellfish Res. 26, 847-854.

Walters, L. J., Miron, G., and Bourget, E. (1999). Endoscopic observations of invertebrate larval substratum exploration and settlement. Mar. Ecol. Prog. Ser. 182, 95-108. doi: 10.3354/meps 182095

Wang, G., Li, N., Zhang, L., Zhang, L., Zhang, Z., and Wang, Y. (2016). IGFBP7 is involved in abalone metamorphosis. Aquaculture 415, 377-384. doi: 10.1016/j. aquaculture.2015.09.031

Wang, G., Li, N., Zhang, L., Zhang, L., Zhang, Z., and Wang, Y. (2015). IGFBP7 promotes hemocyte proliferation in small abalone Haliotis diversicolor, proved by dsRNA and cap mRNA exposure. Gene 571, 65-70. doi: 10.1016/j.gene.2015. 06.051

Wang, G., Liu, B., Tang, B., Zhang, T., and Xiang, J. (2006). Pharmacological and immunocytochemical investigation of the role of catecholamines on larval metamorphosis by $\beta$-adrenergic-like receptor in the bivalve Meretrix meretrix. Aquaculture 258, 611-618. doi: 10.1016/j.aquaculture.2006.04.031

Wassnig, M., Roberts, R. D., Krsinich, A., and Day, R. W. (2010). Effects of water flow rate on growth rate, mortality and biomass return of abalone in slab tanks. Aquac. Res. 41, 839-846. doi: 10.1111/j.1365-2109.2009.02361.x

Weber, J. M. (2011). Metabolic fuels: regulating fluxes to select mix. J. Exp. Biol. 214, 286-294. doi: 10.1242/jeb.047050

Welch, J. M., Forward, R. B., and Howd, P. A. (1999). Behavioral responses of blue crab Callinectes sapidus postlarvae to turbulence: implications for selective tidal stream transport. Mar. Ecol. Prog. Ser. 179, 135-143. doi: 10.3354/meps179135

Williamson, J. E., Nys, R. D., Kumar, N., Carson, D. G., and Steinberg, P. D. (2000). Induction of metamorphosis in the sea urchin Holopneustes purpurascens by a metabolite complex from the algal host Delisea pulchra. Biol. Bull. 198, 332-345. doi: $10.2307 / 1542689$

Wu, F., and Zhang, G. (2013). Suitability of cage culture for Pacific abalone Haliotis discus hannai Ino production in China. Aquac. Res. 44, 485-494. doi: 10.1111/j. 1365-2109.2012.03185.x

Wu, F., and Zhang, G. (2016). Pacific abalone farming in china: recent innovations and challenges. J. Shellfish Res. 35, 703-710. doi: 10.2983/035.035.0317

Xu, Z., Gan, L., Li, T., Xu, C., Chen, K., Wang, X., et al. (2015). Transcriptome profiling and molecular pathway analysis of genes in association with salinity adaptation in Nile tilapia Oreochromis niloticus. PLoS One 10:e0136506. doi: 10.1371/journal.pone.0136506

Xu, Z., Li, T., Li, E., Chen, K., Ding, Z., Qin, J., et al. (2016). Comparative transcriptome analysis reveals molecular strategies of oriental river prawn Macrobrachium nipponense in response to acute and chronic nitrite stress. Fish Shellfish Immun. 48, 254-265. doi: 10.1016/j.fsi.2015.12.005

Yang, B., Qin, J., Shi, B., Han, G., Chen, J., Huang, H., et al. (2012). Molecular characterization and functional analysis of adrenergic like receptor during larval metamorphosis in Crassostrea angulata. Aquaculture 36, 54-61. doi: 10. 1016/j.aquaculture.2012.08.040

Zenteno-Savín, T., Saldierna, R., and Ahuejote-Sandoval, M. (2006). Superoxide radical production in response to environmental hypoxia in cultured shrimp. Comp. Biochem. Phys. C. Toxicol. Pharmacol. 142, 301-308. doi: 10.1016/j.cbpc. 2005.11.001

Zhou, J., Zhu, X., and Cai, Z. (2011). The impacts of bisphenol A (BPA) on abalone (Haliotis diversicolor supertexta) embryonic development. Chemosphere 82, 443-450. doi: 10.1016/j.chemosphere.2010.09.056

Conflict of Interest: The authors declare that the research was conducted in the absence of any commercial or financial relationships that could be construed as a potential conflict of interest.

Publisher's Note: All claims expressed in this article are solely those of the authors and do not necessarily represent those of their affiliated organizations, or those of the publisher, the editors and the reviewers. Any product that may be evaluated in this article, or claim that may be made by its manufacturer, is not guaranteed or endorsed by the publisher.

Copyright (c) 2021 Zhang, Gao, Lyu, Lin, Su, Luo, You and Ke. This is an open-access article distributed under the terms of the Creative Commons Attribution License (CC BY). The use, distribution or reproduction in other forums is permitted, provided the original author(s) and the copyright owner(s) are credited and that the original publication in this journal is cited, in accordance with accepted academic practice. No use, distribution or reproduction is permitted which does not comply with these terms. 